\section{Vectura and Philip Morris: the leopard has not changed its spots}

\author{
Nicholas S Hopkinson (1)
}

The uniquely lethal nature of the tobacco industry's products, ${ }^{1}$ the industry's environmental impact ${ }^{2}$ and its incompatibility with human rights ${ }^{3}$ make the takeover of Vectura, a pharmaceutical company focused on inhaler technology, by tobacco giant Philip Morris International (PMI), extremely unwelcome. The idea that a company which, based on its market share and the global death toll, kills more than a million people every year ${ }^{4}$ should be allowed to expand into the delivery of healthcare has been widely condemned, including by the British Thoracic Society (BTS) (box 1), the European Respiratory Society ${ }^{5}$ and the US COPD Foundation, as well as the American Lung Association and American Thoracic Society who referred to the move as 'reprehensible'. ${ }^{6}$

Tobacco companies have an exhaustively documented history of dishonesty on an industrial scale (www.tobaccotactics.org). This includes lying about the harms of smoking, propagating bogus science and misrepresenting the impact of measures to curb smoking as well as widespread disinformation, and engaging in corrupt practices. A key response has been the development of strict policies to exclude the tobacco industry as a legitimate partner in science and education. The tobacco industry, those it employs and those it funds are therefore banned from membership of professional societies including the British Thoracic Society (BTS). They are also barred from participation in scientific conferences, publishing in respectable journals and, by University policies, from academic collaborations. Article 5.3 of the WHO Framework Convention on Tobacco Control also proscribes tobacco industry influence on public policy.

Now that it has become part of the tobacco industry, Vectura will be subject to these policies. As an illustration, on the day that the takeover was announced, Vectura was expelled from participation and sponsorship of two conferences on inhaler science, with academic speakers stating that they could not attend if Vectura continued to be involved. Vectura

Correspondence to Professor Nicholas S Hopkinson, National Heart and Lung Institute, Imperial College London, London, UK; n.hopkinson@ic.ac.uk
Box 1 British Thoracic Society

Statement on Philip Morris

International's takeover of Vectura

Vectura, a company that for over 20 years has worked to treat lung disease, is now part of the tobacco industry. This is inappropriate, unethical and should have been prevented. The society's policy in relation to the tobacco industry ${ }^{14}$ remains clear :

- In relation to the tobacco industry, BTS will work with colleagues in this country and overseas to combat misinformation about, and the active promotion of, tobacco products, as well as highlighting that tobacco industry funding for academic institutions or research is unacceptable.

- BTS membership is not open to those who have, or have had, paid involvement with tobacco industry at any point in the previous 10 years.

- Any company with links to the tobacco industry will not be approved for participation (eg, as exhibitors) in any society conference or meeting.

- Furthermore, publication of papers funded (wholly or in part) by the tobacco industry in the society's journals, Thorax and BMJ Open Respiratory Research, is specifically prohibited.

employees will need to consider their future, particularly as both BTS and European Respiratory Society policies apply to anyone with a tobacco industry link in the preceding 10 years. Of note, PMI's own statement to investors cautions on 'the ability of PMI to retain and hire key personnel... of Vectura'?

Vectura receives an income stream from several inhalers licensed for the treatment of asthma and COPD. It is reasonable to assume that people with lung disease, and those caring for them, will want to avoid their medication directing money to the tobacco industry wherever possible. Fortunately, as outlined in detail elsewhere, ${ }^{4}$ there are numerous alternatives available, so avoiding initiation of these devices or switching away from them should be straightforward for most people, and has a sound ethical basis in beneficence, non-maleficence, autonomy and distributive justice. ${ }^{4}$ It is important to stress that any adjustment to an individual's inhaled medication must include ensuring that they understand the reason for the switch and have the appropriate support to ensure that they are able to use the device in question.

There is a line of argument to the effect that PMI should be encouraged in its attempt to diversify and move away from cigarettes to other forms of nicotine delivery. There are two separate issues here. First, PMI was only in a position to launch a bid for Vectura because it is massively profitable; the margins on cigarettes sales are three to four times higher than for typical consumer products. ${ }^{8}$ This profitability reflects a profound market failure. Tobacco companies currently evade accountability for huge external costs they generate including ill health, lost productivity and environmental degradation. ${ }^{1-3}$ The global societal aggregated costs of smoking are calculated to be $\$ 2.1$ trillion dollars, $2.9 \%$ of global GDP. ${ }^{9}$ Given its market share, rather than expanding into new areas, PMI should instead be being held liable for around $\$ 240$ billion/year of this.

The second argument is that PMI must be encouraged in its efforts to 'go smokefree', in effect to reform itself and that only this approach, maximising shareholder value, is feasible. As far back as 1954, the year that Doll and Hill proved the link between smoking and lung cancer, Philip Morris lied that it would 'stop business tomorrow' if it 'had any thought or knowledge that in any way we were selling a product harmful to consumers' ${ }^{10}$ In 1994, the presidents and CEOs of the seven largest American tobacco companies testified to Congress under oath that they did not believe nicotine was addictive. PMI is now asserting that it wishes to leverage its 'expertise in inhalation' into something called 'selfcare wellness'. Although tobacco executives would presumably prefer it if their products were not so lethal, they nevertheless remain tolerant of the fact that they are. What we are invited to support is PMI's plan to expand the sales of its new products, eventually shift away from cigarettes (PMI continues to ship 600 billion cigarettes/year) ${ }^{7}$ at its own pace, in whichever markets it chooses, and with no loss of profits. Promoting harm reduction in one country, while marketing cigarettes to young people in another, ${ }^{11}$ all the while opposing tobacco control 
measures. This meagre prospect is capitalist realism, ${ }^{12}$ patiently indulging what England's Chief Medical Officer Chris Whitty has described as 'cancer created by industry for profit'. ${ }^{13}$

Rather than allowing the tobacco industry to use blood money to mount corporate raids on healthcare companies, while giving it a blank cheque to reform in its own time-'Lord, make me chaste, but not yet'-robust action is required. A clear line needs to be taken that Vectura cannot continue business as usual, to act as a deterrent for future tobacco industry takeovers. The UK government must introduce a polluter pays levy on tobacco industry excess profits, as recommended by the All Party Parliamentary Group on Smoking and Health. ${ }^{8}$ In addition the UK, as home to two of the top four tobacco transnationals, has a particular responsibility to accelerate global progress on delivering the measures set out in the FCTC, particularly in low- and middleincome countries, where the majority of deaths from tobacco now occur. Core to this is implementation of Article 5.3 of the FCTC and its guidelines, which require governments to prevent industry interference in public policy and to reject any partnerships and non-binding or nonenforceable agreements with the tobacco industry.

\section{Twitter Nicholas S Hopkinson @COPDdoc}

Contributors NSH wrote this editorial and is the guarantor.

Funding The authors have not declared a specific grant for this research from any funding agency in the public, commercial or not-for-profit sectors.

Competing interests NSH is Chair of ASH(UK) and Medical Director of The British Lung Foundation. The author has completed the ICMJE uniform disclosure form at www.icmje.org/coi_disclosure.pdf and declaration. The author reports no conflicts of interest.

Patient consent for publication Not applicable.

Provenance and peer review Commissioned; externally peer reviewed.

(C) Author(s) (or their employer(s)) 2021. No commercial re-use. See rights and permissions. Published by BMJ.

\section{Check for updates}

To cite Hopkinson NS. Thorax Epub ahead of print: [please include Day Month Year]. doi:10.1136/ thoraxjn-2021-218328

Accepted 26 November 2021

Thorax 2021;0:1-2.

doi:10.1136/thoraxjnl-2021-218328

\section{ORCID ID}

Nicholas S Hopkinson http://orcid.org/0000-00033235-0454

\section{REFERENCES}

1 Murray CJL, Aravkin AY, Zheng P, et al. Global burden of 87 risk factors in 204 countries and territories, 1990-2019: a systematic analysis for the global burden of disease study 2019. The Lancet 2020:396:1223-49.

2 Zafeiridou M, Hopkinson NS, Voulvoulis N. Cigarette smoking: an assessment of tobacco's global environmental footprint across its entire supply chain. Environ Sci Technol 2018;52:8087-94.

3 17th World Conference on Tobacco or Health. Cape town declaration on human rights and a tobacco-free world, 2018. Available: https://unfairtobacco.org/en/ cape-town-declaration/

4 Capstick TGD, Hopkinson NS. Adapting inhaled medication practice in COPD and asthma to avoid funding the tobacco industry. Int J Chron Obstruct Pulmon Dis 2021;16:2917-23.
5 European Respiratory Society. ERS response to the proposed acquisition of Vectura by Philip Morris international, 2021. Available: https://www.ersnet. org/news-and-features/news/ers-response-to-theproposed-acquisition-of-vectura-by-philip-morrisinternational/

6 American Thoracic Society ", American Lung Association. Response to Philip Morris International's Purchase of British Producer of Respiratory Treatments, 2021. Available: https://www.thoracic.org/about/newsroom/ press-releases/ala-and-ats.php

7 Philip Morris International. Investor information July 2021, 2021. Available: https://philipmorrisinternat ional.gcs-web.com/static-files/ded59402-2667-402a9635-40579f0eaa40

8 All Party Parliamentary Group on Smoking and Health. Delivering a smokefree 2030: the all Party parliamentary group on smoking and health recommendations for the tobacco control plan, 2021. Available: https://ash.org.uk/about-ash/all-partyparliamentary-group-on-smoking-health/inquiriesreports/deliveringasf2030appgtcp2021/ 2021

9 The McKinsey Global Institute. Overcoming obesity: an initial economic analysis, 2014. Available: https:// www.mckinsey.com/industries/healthcare-systemsand-services/our-insights/how-the-world-could-betterfight-obesity

10 Cummings KM. A promise is a promise. Tobacco Control 2003;12:117-8.

11 Lagasse LP, Minosa MKR, Moran MB, et al. "Decide Now, Buy Marlboro": examining the influence and appeal of Marlboro's new brand architecture among filipino adolescents. Int J Adolesc Med Health 2021;33.

12 Fisher M. Capitalist realism. Is there no alternative? Zero Books, 2009. https://www.johnhuntpublishing. com/zer0-books/our-books/capitalist-realism

13 Sample I, Stewart H. 'A class act': Chris Whitty, the calm authority amid the Covid crisis. The Guardian, 2021. https://www.theguardian.com/world/2021/ mar/22/a-class-act-sir-chris-whitty-the-calm-authorityamid-covid-crisis-chief-medical-officer

14 British Thoracic Society, 2021. Updated BTS statement: Philip Morris International's acquisition of Vectura. Available: https://www. brit-thoracic.org. uk/news/2021/updated-bts-statement-philip-morrisinternationals-acquisition-of-vectura/ [Accessed 16 Sep, 2021]. 